\title{
Chromatin Modification-Related Protein MEAF6
}

National Cancer Institute

\section{Source}

National Cancer Institute. Chromatin Modification-Related Protein MEAF6. NCI

Thesaurus. Code C111962.

Chromatin modification-related protein MEAF6 (191 aa, $\sim 22 \mathrm{kDa}$ ) is encoded by the human MEAF6 gene. This protein is involved in histone acetylation. 